But the most destructive industry, so far as the forests are concerned, is the manufacture of bast mats, bark boots (lapti), cordage, and other articles prepared from the liber or inner bark of the lime, birch, and willow, chiefly of the former tree. It is computed that $100,000,000$ pairs of lapti are made annually, each pair requiring the bark of four young trees; thus $400,000,000$ trees are cut down every year for shoes! Lime-trees from five to ten years of age, and half-grown birch, are employed for this purposc. Such reckless waste is much to be regretted; and $\mathrm{Mr}$. Werekha otserves that the pines are tapped for their resin and bled to death in from ten to fifteen years, in the same way as the Landes of Gascony were denuded of their pine-forests during the last century.

The previously almost useless aspen, either for fuel or building, has attained to considerable importance within the last few years as a material for paper-making. There are already ten manufactories actively engaged in the preparation of this paper in Russia, and two in Finland; and as vast reserves of this tree have accumulated in the forests, it is expected to prove a source of great riches for many years to come. Timber, of course, is the most valuable article exported, though resinous products and bast mats bring in a large sum. The Scotch pine, spruce fir, birch (for coach-building), and the oak, are the principal and almost the only timbers exported. Speaking of the giant oaks of Russia, Mr. Werekha becomes almost sentimental, for they form the strength of British and French shipbuilders, and occasionally revisit their native country in a form by no means fiattering to national pride, as the Russians are still very small shipbuilders.

\section{THE INDIA IIUSEUM*}

THE India Museum, at present located at Whitehall, has long been known for its extensive and valuable collections of Indian products, a collection too valuable, indeed, not to have been made more available, both for scientific and commercial purposes, than it has been. The removal, however, of the specimens to the galleries at South Kensington will bring them within the reach of ordinary mortals who have neither bodily strength nor inclination to make a pilgrimage to the topmost floor of one of the highest buildings in London.

The importance and value of these collections has to some extent been shown in the several reports which have from time to time been issued from the foreign Office. Dr. Forbes Watson, as Reporter on the Products of India, has done much service in this respect, and Dr. M. C. Cooke, who has drawn up the present report, is no novice amongst Indian gums and resins, having gained an extensive experience from his long official connection with the Muscum.

There are, no doubt, many products of the Indian forests that ought to be included in European commerce, but from the want of a proper knowledge of their uses, have never established themselves in the market. Individually, we have often deplored the prevailing prejudice amongst commercial men in favour of old and well-known commoditics, amounting sometimes even to the absolute rejection of new products, without giving such products a fair trial. Dr. Forbes Watson, in an introductory note to the report under consideration, in reference to this, says it should "be remembered that gums or resins sent over for valuation in the London market are necessarily subject to comparison and competition with the very best qualities of the same substances which come into any of the European markets, and that careful collection is not a too frequent characteristic of Indian products:" Dr. Watson further points out that it is of very great importance to the existing and future trade of India that

* Report by Dr. M. C. Cooke, on the Gums, Resins, Olco-resins, and resinous products in the India Museum, or produced in India. Prepared under the direction of the Reporter on the Products of India, 1874. samples should be sent home in sufficient quantity for report, since this is the only means by which they can be brought under the notice of competent authorities. For this purpose it is suggested that in the casc of gums, resins, \&c., quantities of from 20 lbs. to 25 lbs. would be sufficient for distribution amongst brokers and traders, as well as for analysis and experiments. The necessity, also, of obtaining accurate information on the botanical source of the plant yielding any particular product is strongly urged. The value of accurate specimens gathered at the time of collecting the article itself, whether it be gum, resin, wood, or fibre, must be apparent to everyone, and is strongly advocated in the article "Botany" in the "Admiralty Manual." In all cases such specimens should consist of leaves, flowers, and, where possible, fruits also, securely labelled and numbered, so that no mistake may occur.

This report of Dr. Cooke's is valuable, as it brings together nearly all that has been written on the gums and resinous products of India. The botanical synonymy of each species, with references, is first given; next, a short botanical description; then its habitat, native names, history, description, and uses; and finally, in the case of the most important products, references to the works where the subject has been treated of. Dr. Cooke has brought his report down to the most recent period, for we find under the genus Garcinia, of which the species are described as yielding gum, a description of $G$. Griffithii, with the following note:- "Anderson says of this plant that there is in Maingay's herbarium a plant very like it in habit, but described by him as having a circumsciss anther, which is cultivated in Singapore as the true gamboge of Siam. There still appears to be some doubt as to the source of Siam gamboge, which Dr. Hooker seems disposed to attribute to this tree." The fact is, that in the most recent revision of the order, Garcinia Griffithii of Anderson has been considered identical with $G$. morella, var. pedicellate, to which Siam gamboge has been referred by Hanbury, and which Dr. Hooker thinks has sufficiently distinctive characters to raise it to the rank of a species under the name of $G$. Hanbunyi. Again, Dr. Cooke refers to the very recent work of Flückiger and Hanbury, in which Siam gamboge is attributed to $G$. morelic, var. pedicellata, as stated above. Indeed, throughout the report there are frequent references to the "Pharmacographia," but we are not a little surprised that Stewart and Brandis's "Forest Flora" is not quoted. Thus, for instance, at p. 24 of the report, the Marking Nut, Sonccurpus anacardium, is dismissed with very few lines: while in the "Forest Flora" is an excellent description of the tree; of the wood, which "is full of an acrid juice which causes swelling and irritation, so that the timber cutters object to fell it unless it has been ringed for some time;" and of the fruit and the black varnish, which is prepared from the pericarp, and which is used mixed with lime-water for marking cotton. Small consignments of these fruits occasionally arrive in this country, and not long since a quantity of a very fine kind came into the hands of a London house. I. R. J.

\section{UMBELLULA, OR CLUSTER POI YP}

$A$ BOUT six months since (vol. x. p. 142) we referred to a letter from Prof. Wyville Thomson, in which he mentions having brought up from a depth of nearly I,500 feet, between Prince Edward's Island and the Crozets (Kerguelen's Land), specimens of an Umbcllula. When the Challenger was between the coasts of Portugal and Madeira, several specimens of another species of the same rare genus, but from a depth of about 2,000 feet, were also dredged up. The history of these curious Cluster Polyps is interesting. Some hundred and twenty years ago, and some one and twenty years before $M$. Kerguelen discovered the land now bearing his name, 